\title{
СУЧАСНА ПАРАДИГМА ДЕРЖАВНОГО РЕГУЛЮВАННЯ СИСТЕМИ УПРАВЛІННЯ У СФЕРІ ОХОРОНИ ЗДОРОВ'Я
}

\section{Борщ В. I.}

\section{ВСТУП}

Згідно 3 Конституцією України людина має право на життя та здоров'я, право на недоторканність приватного життя, право на безпеку, як одну з найвищих цінностей національної правової системи ${ }^{1}$. Серед інших прав, передбачених Конституцією, окремо зазначаємо право на медичну допомогу, яка гарантує фізичне існування людини i яке має важливе значення для підтримки та покращення здоров'я української нації.

В Україні державне регулювання охорони здоров'я $\epsilon$ важливим складовим елементом державної політики та управління галуззю, проте до сьогодні законодавча база у галузі як ключовий інструмент державного управління не відокремлена у правовий інститут. Системний аналіз ряду наукових праць щодо формування та розвитку права людини на охорону здоров'я підтверджує наявність ефективних спроб формування засад відповідальності за здоров'я населення країни.

Формування державної політики в галузі охорони здоров'я України характеризується загальними закономірностями, які $є$ універсальними для більшості країн світу. За даними 3.С. Гладуна, до складу нормативно-правової бази, що регулює діяльність сфери охорони здоров'я, яка була створена в період незалежності України, входить понад 5,5 тисячі законодавчих та підзаконних нормативно-правових актів, що мають комплексний характер 2 .

У Законі України «Основи законодавства України про охорону здоров’я» від 19 листопада 1992 р. (№ 2801-XII, редакція від 16.01.2020 р.) $)^{3}$ визначається, що держава та громада гарантують пріоритет охорони здоров'я в діяльності країни. Під час формування

\footnotetext{
${ }^{1}$ Конституція України : в редакції від 01 січня 2020 р. № 254к/96-ВР. Відомості Верховної Ради Украӥни. 1996. № 30.

2 Гладун 3.С. Адміністративно-правове регулювання охорони здоров'я населення в Україні : монографія. Київ : Юрінком Інтер, 2007. 720 с.

3 Основи законодавства України про охорону здоров'я : Закон України від 19 листопада 1992 р. (№ 2801-XII, редакція від 16 січня 2020 р.) URL : https://zakon.help/law/2801-XII.
} 
державної політики держава дотримується принципів міжнародних договорів, які були ратифіковані Україною.

Свропейський кодекс соціального захисту (European Code of Social Security; Страсбург, 1962 р.) ${ }^{4}$ та Хартія соціальних прав (Charter on Social Rights; Гавана, 1982 р. $)^{5}$ - це політичні документи, які $€$ основними для більшості країн у розробці державної політики в галузі охорони здоров'я. Основи формування державної політики та стратегії охорони здоров'я були задекларовані на першій Міжнародній конференції з питань зміцнення здоров'я (I International Conference on Health Promotion; Канада, 1986 р.), це Оттавська хартія сприяння зміцненню здоров'я (Ottawa Charter for Health Promotion $)^{6}$. Відповідно до прийнятих рішень зазначається впровадження принципово нової управлінської технології в галузі охорони здоров'я, заснованої на міжгалузевому підході.

На конференції було встановлено, що детермінанти здоров'я $€$ біологічно та соціально обумовленими та запрограмованими, а державна політика щодо збереження та зміцнення здоров'я повинна поєднувати різноманітні, але взаємодоповнюючі підходи, включаючи законодавство, фіскальні заходи, оподаткування та організаційні зміни, вимагати визначення перешкод для прийняття здорової державної політики в галузі охорони здоров'я та шляхи їх усунення ${ }^{7}$.

Відповідно до Оттавської хартії у процесі сприяння збереженню та зміцненню здоров'я повинні бути реалізовані такі напрями:

1) формування політики охорони здоров'я на основі міжгалузевого підходу;

2) створення сприятливого середовища, яке засноване на соціальноекологічному підході до здоров'я;

3) посилення ролі громад щодо визначення пріоритетів, прийняття рішень, стратегій планування та їх реалізації з метою збереження та зміцнення здоров'я;

4) розвиток особистісних та соціальних навичок шляхом надання інформації, освіти для здоров'я та вдосконалення життєвих навичок;

4 European Code of Social Security. Treaty № 048. URL : https://www.coe.int/en/web/conventions/full-list/-/conventions/treaty/048.

5 Charter on Social Rights №. 995_418 (February 15, 1982). URL : http://zakon.rada.gov.ua/laws/show/995_418?lang=en.

${ }^{6}$ Charter adopted at an international conference on health promotion. The move towards a new public health (November 17-21, 1986 Ottawa, Ontario, Canada). URL : https://www.who.int/healthpromotion/conferences/previous/ottawa/en/.

${ }^{7}$ Charter adopted at an international conference on health promotion. The move towards a new public health (November 17-21, 1986 Ottawa, Ontario, Canada). URL : https://www.who.int/healthpromotion/conferences/previous/ottawa/en/. 
5) переорієнтація системи охорони здоров'я на профілактику захворювань - превентивну медицину - та первинну медичну допомогу.

Таким чином, основними стратегічними завданнями які направлені на реалізацію принципів Оттавської хартії, на світовому рівні є:

1) рух до «здорової» державної політики та формування чіткої політичної орієнтації збереження та зміцнення здоров'я та справедливості доступу до медичної допомоги;

2) протидія несприятливим умовам навколишнього середовища: шкідливі умови життя та довкілля, неправильне харчування, виснаження ресурсів, забруднення навколишнього середовища, небезпека на виробництві, житлові умови населення тощо;

3) реагування на розрив у наданні медичної допомоги всередині суспільства та між різними верствами населення з метою зменшення цієї нерівності;

4) визнання населення країни основним капіталом; а отже, й забезпечення підтримки за допомогою фінансових та інших механізмів впливу;

5) переорієнтація медичної галузі країни на превентивну медицину та політику здоров'язбереження;

6) визнання здоров'я як основного соціального капіталу та політично значущою проблемою.

Надання переваги праву на здоров'я було визначено у статті 12 Загальних коментарів Комітету 3 економічних, соціальних та культурних прав ${ }^{8}$.

Міжнародні хартії та декларації $\epsilon$ основою формування національної політики охорони здоров'я у переважній більшості країн світу. Вони передбачають:

- прогресивну реалізацію державної політики та стратегій охорони здоров'я з використанням максимально доступних ресурсів;

- недопустимість регресії права, тобто державний уряд не має дозволяти наявному стану охорони здоров'я погіршуватися'.

Основними ознаками права на здоров'я $€$ його доступність, прийнятність та якість.

${ }^{8}$ General Comment № 14 (2000). The right to the highest attainable standard of health (article 12 of the International Covenant on Economic, Social and Cultural Rights) URL : https://tbinternet.ohchr.org/_layouts/treatybodyexternal/ Download.aspx?symbolno $=\mathrm{E} \% 2 \mathrm{fC} .12 \% 2 \mathrm{f} 2000 \% 2 \mathrm{f} 4 \&$ Lang=en.

${ }^{9}$ Truba V., Borshch V., Haran O. Methodological frameworks for state regulation of health care system in the post-soviet countries. Baltic Journal of economic studies. 2018. Vol. 4. N 5. Pp. 364-370. DOI: https://doi.org/10.30525/2256-0742/2018-4-5-364-370. 
Таким чином, у всьому світі право людини на здоров'я має забезпечуватися національними державними програмами, стратегією розвитку та політикою в галузі охорони здоров'я на національному, регіональному та локальному рівнях, впроваджуючи основні детермінанти здоров'я як частину комплексного підходу до охорони здоров'я та прав людини ${ }^{10}$.

\section{1. Концептуальні засади державного регулювання сфери охорони здоров'я}

Аналізуючи систему державної політики та державного регулювання сфери охорони здоров'я України, необхідно найперше визначитися 3 основними поняттями проблематики: «державне управління в сфері охорони здоров'я», «державне регулювання охорони здоров'я», «державна політика та державна стратегія розвитку сфери охорони здоров'я».

Державне управління передбачає прямий управлінський вплив на об'єкти управління за допомогою адміністративних повноважень та методів, що характеризуються директивними вказівками та інструкціями щодо їх виконання ${ }^{11}$.

Економічна наука визначає державне управління як організуючий і регулюючий процес впливу держави на діяльність суб'єктів певної сфери 3 метою іiі впорядкування та підвищення результативності господарювання ${ }^{12}$.

Правова наука визначає поняття «державного регулювання» як систему державних заходів (організаційно-правових, економічних тощо) у сфері соціальних, економічних, політичних, культурних та інших суспільних процесів з метою їх узгодження, упорядкування, формування загальних правил та норм соціальної поведінки та запобігання будь-яким несприятливим наслідкам у суспільстві ${ }^{13}$.

Із позиції економічної науки, державне регулювання розглядається як «система заходів задля здійснення підтримуючої, компенсаційної та регулюючої діяльності держави, спрямованої на створення відповідних умов ефективного функціонування ринку та вирішення складних

${ }^{10}$ Human rights and health. WHO : official web-site. URL : http://www.who.int/ news-room/fact-sheets/detail/human-rights-and-health.

11 Гладун 3.С. Адміністративно-правове регулювання охорони здоров'я населення в Україні : монографія. Київ : Юрінком Інтер, 2007. 720 с.

${ }^{12}$ Швайка Л.А. Державне регулювання економіки : Навчальний посібник. Київ : Знання, 2006. 435 с.

13 Юридична енциклопедія : в 6 т. Т. 3. Київ : Вид-во «Укр. енцикл.» ім. М.П. Бажана, 2001. 782 с. 
соціально-економічних проблем розвитку національної економіки та всього суспільства» ${ }^{14}$.

Л.А. Швайка розглядає державне регулювання економіки як «сферу діяльності органів державної влади щодо цілеспрямованого впливу на поведінку суб'єктів господарювання шляхом застосування різноманітних методів і засобів» ${ }^{15}$.

Державне регулювання передбачає лише встановлення обмежень та меж для закладів та установ, за якими вони могли б вільно працювати.

Отже, державне управління та державне регулювання - це два різних види державної діяльності. Державне регулювання, на відміну від державного управління, спрямоване не лише на об'єкт управління, а й на середовище, в якому цей суб'єкт здійснює свою діяльність. Тому вони між собою відрізняються широтою владного впливу ${ }^{16}$.

У сфері охорони здоров'я державне управління представляє собою комплексну ієрархічну управлінську систему у сфері охорони здоров'я, що має національний, регіональний та локальний рівні: держава, області, райони та окремі населені пункти (зокрема міста, селища, села, тобто адміністративні території та громади), а також заклади охорони здоров'я різних форм власності.

Здійснення медичної діяльності в національні системі охорони здоров'я забезпечується за рахунок механізмів державного регулювання в межах державної політики. Отже, державне регулювання в сфері охорони здоров'я передбачає формування загальних норм та правил здійснення медичної діяльності, тобто медичної допомоги, визначення відповідальності за дотримання цих правил, впливу уряду та його органів на діяльність закладів охорони здоров'я ${ }^{17}$.

За думкою В.В. Шевчук, «у напрямках державного регулювання охорони здоров'я знаходять відображення способи і форми реалізації соціальних обов'язків у сфері охорони здоров'я населення, стратегія та пріоритети зміцнення здоров'я та профілактики захворювань» ${ }^{18}$.

14 Державне регулювання економіки (2006). URL : https://library.if.ua/book/ 72/5235.html.

${ }^{15}$ Швайка Л. А. Державне регулювання економіки : навчальний посібник. Київ : Знання, 2006. 435 с.

16 Гладун 3.С. Державне управління в галузі охорони здоров'я. Тернопіль : Академкнига, 2000. 312 с.

17 Гладун 3.С. Державне управління в галузі охорони здоров'я. Тернопіль : Академкнига, 2000. 312 с.

${ }^{18}$ Шевчук В.В. Удосконалення державного регулювання інноваційного розвиту системи охорони здоров'я України : дис. ... канд. наук з держ. упр. Миколаїв, 2017. 219 c. 
Отже, державне регулювання має засновуватися на адекватно сформованій державній політиці та стратегії розвитку галузі, державних медичних програмах та стандартах, а також механізмах їх обов'язкового виконання, державному контролі та примусі з боку владних органів. Уряд має використовувати не лише юридичні, але й організаційні, фінансові, кадрові та інші інструменти впливу. Таким чином, державне регулювання у сфері охорони здоров'я повинно базуватися на державному бюджеті, податковій, кредитній, фінансовоінвестиційній системах, науковій та технічній політиці країни, тобто регулювання сферою має забезпечуватися через різні регламенти та інструменти: державний бюджет, державний контроль, податкову систему, стандарти, митні тарифи тощо.

У межах державного управління $є$ важливим розуміння поняття «державної політики». С.В. Петрова розглядає державну політику у сфері охорони здоров'я як «комплекс прийнятих загальнодержавних рішень чи взятих зобов'язань щодо збереження і зміцнення фізичного і психічного здоров'я та соціального благополуччя населення держави як найважливішої складової частини іії національного багатства шляхом реалізації сукупності політичних, організаційних, економічних, правових, соціальних, наукових, медичних заходів з метою збереження громадського здоров'я» ${ }^{19}$.

Державна стратегія розвитку сфери охорони здоров'я - це документ, який визначає мету, завдання та процедури для центральних, місцевих органів виконавчої влади і органів місцевого самоврядування для досягнення стратегічних цілей із метою розвитку сфери охорони здоров'я у довгостроковому періоді з урахуванням державної політики, національної нормативно-правової бази та міжнародних стандартів та норм $^{20}$.

В.В. Шевчук зазначає, що «механізм реалізації державної політики у сфері охорони здоров'я ... [представляє собою] ... комплекс стратегічних цілей і пріоритетів, сформованих на основі розподілу на підпункти цілей державної соціально-економічної політики, методів корпоративного та публічного менеджменту, інструментів, важелів, стимулів, що підтримують підсистеми, за допомогою яких управлінська система створює необхідні умови для ефективного

${ }^{19}$ Петрова С.В. Державна політика України у сфері охорони здоров'я в контексті реформи медичного обслуговування. Теорія та практика державного управління імісиевого самоврядування: Електронний збірник. 2014. № 2. URL : http://el-zbirn-du.at.ua/index/zmist_2014_2/0-16.

20 Жаліло Л.І., Мартинюк О.І. Стратегії змін у сфері охорони здоров'я в умовах соціально-економічних реформ в Україні. URL : http://academy.gov.ua/ej/ej14/txts/Zhalilo.pdf. 
функціонування взаємопов'язаних суб'єктів інституційної структури сфери охорони здоров'я та досягнення соціально важливих результатів на основі зворотних зв'язків» ${ }^{21}$.

Одним із головних завдань соціально орієнтованої країни $\epsilon$ пошук балансу між інтересами громадян країни, що потребують якісної та висококваліфікованої медичної допомоги, та постачальниками медичних послуг. Так, з одного боку, уряд має задовольнити очікування та інтереси своїх громадян у наданні медичної допомоги, а з іншого - задовольнити інтереси працівників галузі.

На нашу думку, державне регулювання системи управління у сфері охорони здоров'я - це системний, планомірний вплив державних інституцій та інститутів на діяльність суб'єктів макроекономічного середовища охорони здоров'я, враховуючи стабільні умови функціонування ринкового механізму господарювання, основною метою якого є дотримання пріоритетної лінії державної політики щодо фінансового, економічного та соціального зростання індикаторів національного макроекономічного середовища охорони здоров'я, враховуючи пріоритет заходів із збереження та зміцнення здоров'я людського капіталу країни. Відповідно до дослідження В.В. Шевчука, «в принципово нових умовах розвитку суспільства державне регулювання системою охорони здоров'я має відповідати не лише новій парадигмі інноваційного розвитку охорони здоров'я в рамках застосування сучасних управлінських технологій, а й новим принципам організації охорони здоров'я населення: міжсекторального підходу до охорони здоров'я, відповідальності держави за демографічну безпеку нації, відповідальності і зацікавленості громадян у зміцненні власного здоров'я, пріоритетам профілактичних заходів та первинної медикосанітарної допомоги ${ }^{22}$. Державне регулювання інноваційним розвитком охорони здоров'я має включати моніторинг ресурсів охорони здоров'я та результатів діяльності системи охорони здоров'я, регулювання в рамках систем «централізація - децентралізація», «державне регулювання та самоврядування», «державні та ринкові механізми, методи та інструменти регулювання», «відомча, державна та приватна системи охорони здоров'я», «міжсекторальна взаємодія системи охорони здоров'я громадян».

${ }^{21}$ Шевчук В.В. Удосконалення державного регулювання інноваційного розвиту системи охорони здоров'я України : дис. ... канд. наук з держ. упр. Миколаїв, 2017. 219 c.

${ }^{22}$ Шевчук В.В. Удосконалення державного регулювання інноваційного розвиту системи охорони здоров'я України : дис. ... канд. наук 3 держ. упр. Миколаїв, 2017. 219 c. 
Наголошуємо, що державне регулювання охорони здоров'я спрямоване на створення сприятливих організаційно-господарських та фінансових умов, з урахуванням ринкових механізмів господарювання. Таким чином, регулювання не передбачає втручання держави в організаційну та професійну діяльність, за винятком випадків, визначених законом.

\section{2. Державне регулювання сфери охорони здоров'я в Україні}

Основною метою державного регулювання сфери охорони здоров'я України є зміцнення та збереження здоров'я населення, забезпечення висококваліфікованої медичної допомоги, поліпшення якості життя та збереження генофонду нації.

Для реалізації цієї мети державою було визначено наступні основні завданнями регулювання охорони здоров'я:

1) створення сприятливих організаційних i фінансових умов діяльності та розвитку закладів охорони здоров'я всіх форм власності;

2) контроль якості медичних послуг та медичної допомоги;

3) формування нормативно-правової бази, що забезпечує рівні умови для постачальників медичних послуг;

4) реалізація соціально-демографічної політики, спрямованої на підвищення рівня народжуваності та зниження рівня смертності;

5) формування вільного доступу до медичної допомоги для всіх верств населення;

6) забезпечення санітарно-епідеміологічного добробуту населення;

7) забезпечення ефективної багатоканальної фінансової системи за рахунок збільшення державної фінансової підтримки в галузі охорони здоров'я та пошук альтернативних джерел фінансування галузі;

8) заохочення населення до здорового способу життя;

9) активізація розвитку медичної та фармацевтичної промисловості, включаючи виробництво медичних виробів та виробів медичного призначення, виробництво фармацевтичних препаратів тощо;

10) активізація науково-дослідної діяльності та ринку новацій усфері охорони здоров'я: інноваційних медичних технологій, інноваційного обладнання та устаткування тощо;

11) створення сприятливих умов для професійного розвитку персоналу в сфері охорони здоров'я: сприяння процесам неперервної медичної освіти, управлінської освіти в сфері охорони здоров'я тощо.

Ю.М. Ридзель визначає такі функції i задачі державного регулювання розвитку у сфері охорони здоров'я, зокрема:

1) інформаційна функція: виявлення та управління факторами, що впливають на появу кризових явищ у системі охорони здоров'я; 
забезпечення використання інформаційних технологій у галузі; інформаційна взаємодія між основними суб'єктами;

2) ресурсна: забезпечення кадровими ресурсами сфери охорони здоров'я, бюджетно-фінансова та грошова-кредитна політика держави, а також управління державними витратами, закупівлями та позиками;

3) інноваційна: забезпечення інституційних перетворень зовнішнього середовища, сприятливих для розвитку інновацій; формування пріоритетних напрямів розвитку галузі; стимулювання інноваційної діяльності та розвитку трансферу медичних технологій;

4) контрольна: організація постійного моніторингу за станом галузі; аналіз потенціальних наслідків розвитку галузі; оцінка ефективності заходів ${ }^{23}$.

Принциповою особливістю сучасної державно політики у сфері охорони здоров'я, за думкою В.В. Шевчук, є те, що «вона реалізується у контексті адміністративної та бюджетної реформ, спрямованих на перехід від концепції управління витратами до управління за результатами» ${ }^{24}$.

Державне регулювання у сфері охорони здоров'я має дві основні підсистеми, які представлені на рис. 1.

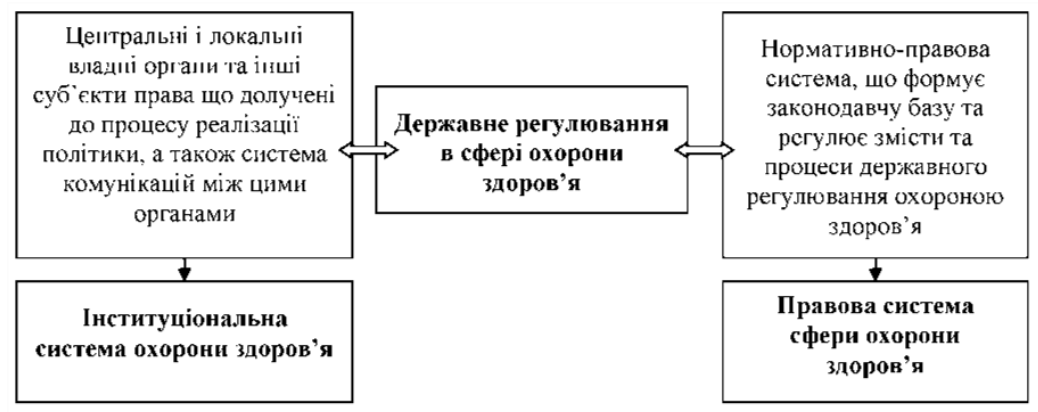

\section{Рис. 1. Підсистеми державного регулювання сферою охорони здоров'я} Джерело: сформовано автором

${ }^{23}$ Ридзель Ю.М. Державне регулювання інноваційного розвитку сфери охорони здоров'я України : дис. ... канд. екон. наук. Чернігів, 2020. 258 с.

24 Шевчук В.В. Підходи до реалізації механізмів державного регулювання інноваційного розвитку системи охорони здоров'я України. Наукові праці [Чорноморського державного університету імені Петра Могили комплексу «Києво-Могилянська академія»]. Сер. : Державне управління. 2014. Т. 235. Наук Вип. 223. С. 128-132. 
Об'єктами державного регулювання охорони здоров'я є особливі взаємозв'язки та явища, медичний ринок та його структурні елементи, система, територіальна, галузева та функціональна підсистеми охорони здоров’я України, а також принципи ії організації та функціонування.

Виділяють два типи об'єктів державного регулювання охорони здоров'я:

- матеріальні;

- нематеріальні.

До першої групи належать заклади охорони здоров'я різних форм власності, лікарські засоби, персонал, основний капітал та фінансові ресурси цих закладів. До другої належать службові відносини в закладах охорони здоров'я, відносини між покупцями та постачальниками медичних послуг тощо.

Але головним об'єктом такого регулювання $є$ здоров'я людини та його стан, на який можна впливати, поліпшуючи його.

Основними суб'єктами державного регулювання охорони здоров'я в Україні $\epsilon$ Верховна Рада України та Уряд, центральні органи виконавчої влади, серед яких Міністерство охорони здоров'я України, а також місцеві органи виконавчої влади, до яких належать департаменти охорони здоров'я обласних державних адміністрацій, департаменти охорони здоров'я міських рад ${ }^{25}$, які здійснюють функції управління охороною здоров'я в країні.

Діяльність цих органів регламентуються ст. 13 та ст. 14 Закону України «Основи законодавства про охорону здоров'я» ${ }^{26}$.

Функціональне навантаження суб'єктів державного регулювання охорони здоров'я в Україні представлено у табл. 1.

У межах державного регулювання у галузі охорони здоров'я можна виділити два напрямки:

- направлені на вирішення політичних завдань;

- направлені на вдосконалення механізмів управління.

Перший - політичний - аспект полягає в досягненні соціальних та економічних цілей. Другий - управлінський - аспект стосується механізмів управління охороною здоров'я, які мають змішану природу, відображаючи складність взаємовідносин між постачальниками послуг.

${ }^{25}$ Гладун 3.С. Державне управління в галузі охорони здоров'я. Тернопіль : Академкнига, 2000. 312 с.

${ }^{26}$ Основи законодавства України про охорону здоров'я : Закон України від 19 листопада 1992 р. (№ 2801-XII, редакція від 16 січня 2020 р.) URL : https://zakon.help/law/2801-XII. 
Таблиця 1

Характеристика основних функцій суб'єктів державного регулювання охорони здоров'я України

\begin{tabular}{|c|c|c|}
\hline № & $\begin{array}{c}\text { Суб'скт державного } \\
\text { регулювання охорони } \\
\text { здоров'я Украӥни }\end{array}$ & $\begin{array}{l}\text { Характеристика функціональних } \\
\text { обов'язків у сфері охорони здоров'я }\end{array}$ \\
\hline 1. & Верховна Рада України & $\begin{array}{l}\text { формує державну політику про охорони } \\
\text { здоров'я через закріплення конституційних } \\
\text { і законодавчих засад охорони здоров'я, } \\
\text { визначення ії мети, головних завдань, } \\
\text { напрямів, принципів і пріоритетів, } \\
\text { встановлення нормативів і обсягів } \\
\text { бюджетного фінансування, створення } \\
\text { системи відповідних кредитно-фінансових, } \\
\text { податкових, митних та інших регуляторів, } \\
\text { затвердження загальнодержавних програм } \\
\text { охорони здоров'я. }\end{array}$ \\
\hline 2. & Президент України & $\begin{array}{l}\text { несе особисту відповідальність за } \\
\text { реалізацію державної політики охорони } \\
\text { здоров'я, виступає гарантом влади, } \\
\text { проводить у життя державну політику } \\
\text { охорони здоров'я та здійснює інші } \\
\text { повноваження, передбачені } \\
\text { Конституцією України. }\end{array}$ \\
\hline 3. & Кабінет міністрів України & $\begin{array}{l}\text { організує розробку та здійснення } \\
\text { державних цільових програм, створює } \\
\text { економічні, правові та організаційні } \\
\text { механізми, що стимулюють ефективну } \\
\text { діяльність у сфері охорони здоров’я, } \\
\text { забезпечує розвиток мережі закладів } \\
\text { охорони здоров'я, укладає міжурядові } \\
\text { угоди і координує міжнародне } \\
\text { співробітництво з питань охорони } \\
\text { здоров'я, а також у межах своєї } \\
\text { компетенції здійснює інші повноваження, } \\
\text { покладені на органи виконавчої влади } \\
\text { в сфері охорони здоров'я. }\end{array}$ \\
\hline 4. & $\begin{array}{l}\text { Міністерство охорони } \\
\text { здоров'я України }\end{array}$ & $\begin{array}{l}\text { у межах своєї компетенції планує } \\
\text { і здійснює заходи щодо реалізації } \\
\text { державної політики України, виконання } \\
\text { програм у галузі охорони здоров’я та } \\
\text { у сфері розвитку медичної науки. }\end{array}$ \\
\hline
\end{tabular}


Продовження таблиці 1

\begin{tabular}{|c|c|c|}
\hline № & $\begin{array}{c}\text { Суб'скт державного } \\
\text { регулювання охорони } \\
\text { здоров'я України }\end{array}$ & $\begin{array}{l}\text { Характеристика функціональних } \\
\text { обов'язків у сфері охорони здоров'я }\end{array}$ \\
\hline 5. & $\begin{array}{l}\text { Інші міністерства } \\
\text { та відомства України }\end{array}$ & $\begin{array}{l}\text { Міністерство внутрішніх справ України, } \\
\text { Міністерство інфраструктури України, } \\
\text { Міністерство оборони України, Служба } \\
\text { безпеки України, які мають свої власні } \\
\text { медичні служби, що забезпечують } \\
\text { медичними і профілактичними } \\
\text { послугами відповідні категорії } \\
\text { службовців та членів їх сімей. Державна } \\
\text { кримінально-виконавча служба України } \\
\text { є відповідальною за організацію } \\
\text { медичних та профілактичних заходів } \\
\text { усередині пенітенціарної системи. }\end{array}$ \\
\hline 6. & $\begin{array}{l}\text { Національна служба } \\
\text { здоров’я України }\end{array}$ & $\begin{array}{l}\text { реалізує державну політику у сфері } \\
\text { державних фінансових гарантій } \\
\text { медичного обслуговування населення; } \\
\text { виконання функцій замовника медичних } \\
\text { послуг та лікарських засобів за } \\
\text { програмою медичних гарантій; внесення } \\
\text { на розгляд Міністра охорони } \\
\text { здоров'я пропозицій щодо забезпечення } \\
\text { формування державної політики у сфері } \\
\text { державних фінансових гарантій } \\
\text { медичного обслуговування населення. }\end{array}$ \\
\hline 7. & $\begin{array}{l}\text { Верховна Рада АР Крим, } \\
\text { Рада Міністрів АР Крим, } \\
\text { обласні ради, обласні } \\
\text { державні адміністрації } \\
\text { (ОДА), управління охорони } \\
\text { здоров'я ОДА, Київська та } \\
\text { Севастопольська міські ради, } \\
\text { Київська та Севастопольська } \\
\text { міські державні } \\
\text { адміністрації, управління } \\
\text { охорони здоров’я Київської } \\
\text { та Севастопольської міських } \\
\text { державних адміністрацій }\end{array}$ & $\begin{array}{l}\text { забезпечення реалізації державної } \\
\text { політики охорони здоров’я на } \\
\text { відповідних територіях, і передані їм } \\
\text { в управління рішеннями вищих органів } \\
\text { державної влади та районними чи } \\
\text { обласними радами заклади охорони } \\
\text { здоров'я державної власності та заклади } \\
\text { охорони здоров’я, що перебувають } \\
\text { у спільній власності територіальних } \\
\text { громад (республіканські Автономної } \\
\text { Республіки Крим та обласні лікарні, } \\
\text { діагностичні центри тощо) }\end{array}$ \\
\hline 8. & $\begin{array}{l}\text { Районні ради, районні } \\
\text { державні адміністрації, } \\
\text { центральні районні лікарні, } \\
\text { сільські, селищні ради }\end{array}$ & $\begin{array}{l}\text { реалізують державну політику у сфері } \\
\text { охорони здоров’я в межах своїх } \\
\text { повноважень, передбачених } \\
\text { законодавством }\end{array}$ \\
\hline 9. & $\begin{array}{l}\text { Міські ради, виконавчі } \\
\text { комітети міських рад, } \\
\text { управління (відділи) охорони } \\
\text { здоров'я міських рад }\end{array}$ & $\begin{array}{l}\text { здійснюють управління закладами охорони } \\
\text { здоров’я, організацію медичного } \\
\text { обслуговування населення, забезпечують } \\
\text { доступність медичного обслуговування, } \\
\text { розвиток лікувальних закладів усіх форм } \\
\text { власності. }\end{array}$ \\
\hline
\end{tabular}

Джерело: сформовано автором на основі ${ }^{27}$

${ }^{27}$ Руснак Л.М. Особливості державного управління діяльності у сфері охорони здоров'я. Держава та регіони. Серія : Право. 2013. № 2 (40). С. 58-63. URL : http://nbuv.gov.ua/j-pdf/drp_2013_2_13.pdf. 
Вони направлені на більш ефективне й раціональне використання фінансових, матеріальних і людських ресурсів галузі та передбачають регулювання: якості надання медичної допомоги та ефективності діяльності закладів охорони здоров'я; доступності до медичної допомоги (у т. ч. шляхом запровадження відповідної податкової політики); поведінки постачальників; поведінки платників; ринку медичних послуг та фармацевтичного ринку; діяльності керівників закладів охорони здоров'я, лікарів та інших медичних працівників. А також сприяння державно-приватному партнерству та трьохсторонній моделі співпраці між соціальним, політичним та фінансовим секторами у сфері охорони здоров'я з метою досягнення основних цілей та завдань, що поставлені перед системою охорони здоров'я; формування ключової стратегії та сприяння формуванню належного підгрунтя для іiі реалізації на індивідуальних соціальних i структурних рівнях; сприяння громадської активності та співпраці у питаннях планування, управління, фінансування тощо у сфері охорони здоров'я; формування належної нормативно-законодавчої бази, спрямованої на подолання кризових ситуацій в сфері охорони здоров'я та забезпечення досягнення ії̈ основних цілей та завдань.

Модель державного регулювання системи управління у сфері охорони здоров'я представлена на рис. 2 .

Суб'єкти державного регулювання впливають на об'єкти за допомогою сукупності методів для досягнення основної мети. Основні методи державного регулювання, що використовуються національними владними органами узагальнено автором у табл. 3 .

Методи державного регулювання у сфері охорони здоров'я - це інструменти державного впливу на бізнес-середовище, ринкову інфраструктуру та неприбутковий економічний сектор для забезпечення умов із метою іхнього ефективного функціонування, враховуючи до уваги політику галузі охорони здоров'я.

Методи державного регулювання у сфері охорони здоров'я можна класифікуються наступним чином:

1) за засобами державного регулювання:

- адміністративні методи;

- економічні методи;

2) за формами державного регулювання:

- прямі методи;

- непрямі методи;

3) за типом ринку охорони здоров'я:

- методи регулювання ринку медичних послуг; 
- методи регулювання ринку медичного обладнання, технологій та новацій у галузі охорони здоров'я;

- методи регулювання фармацевтичного ринку;

- методи регулювання ринку медичного страхування;

- методи регулювання ринку праці медичного персоналу та ринку медичної освіти;

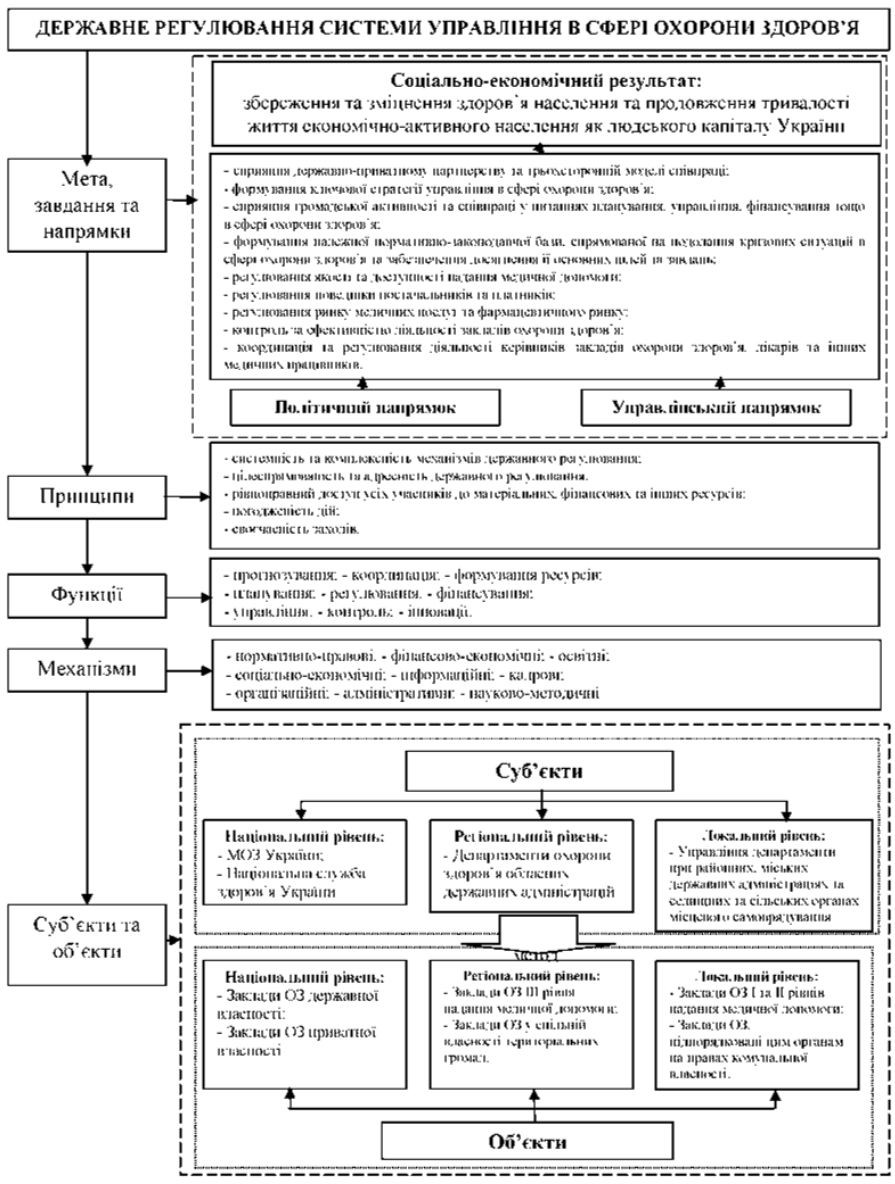

Рис. 2. Модель державного регулювання системи управління у сфері охорони здоров'я України

Джерело: розроблено автором 
Комплекс методів державного регулювання

у сфері охорони здоров'я України

\begin{tabular}{|c|c|c|c|}
\hline \multicolumn{4}{|c|}{ 1. Ринок медичних послуг } \\
\hline \multirow{3}{*}{$\begin{array}{c}\text { Адміністративні } \\
\text { (директивні) } \\
\text { методи }\end{array}$} & \multicolumn{3}{|c|}{$\begin{array}{l}\text { Економічні методи } \\
\end{array}$} \\
\hline & \multirow[b]{2}{*}{$\begin{array}{c}\text { Прямі } \\
\text { економічні } \\
\text { методи }\end{array}$} & \multicolumn{2}{|c|}{$\begin{array}{c}\text { Непрямі економічні методи, направлені } \\
\text { на стимулювання }\end{array}$} \\
\hline & & $\begin{array}{c}\text { Розширення } \\
\text { пропозиції та } \\
\text { підвищення } \\
\text { якості }\end{array}$ & $\begin{array}{c}\text { Розширення } \\
\text { платоспроможного } \\
\text { попиту на товари та } \\
\text { послуги на ринку }\end{array}$ \\
\hline $\mathbf{1}$ & 2 & $\mathbf{3}$ & 4 \\
\hline $\begin{array}{l}\text { - Ліцензування } \\
\text { діяльності; } \\
\text { - Акредитація та } \\
\text { реєстрація закладів } \\
\text { охорони здоров'я; } \\
\text { - Стандартизація } \\
\text { якості медичних } \\
\text { послуг. }\end{array}$ & $\begin{array}{l}\text { - Державні } \\
\text { видатки на } \\
\text { фінансування } \\
\text { сфери охорони } \\
\text { здоров'я. }\end{array}$ & $\begin{array}{l}\text { - Звільнення від } \\
\text { оподаткування } \\
\text { ППП окремих } \\
\text { закладів охорони } \\
\text { здоров’я } \\
\text { державної } \\
\text { власності; } \\
\text { - Звільнення } \\
\text { закладів охорони } \\
\text { здоров’я від } \\
\text { земельного } \\
\text { податку. }\end{array}$ & $\begin{array}{l}-\quad \text { Звільнення від } \\
\text { оподаткування ПДВ } \\
\text { операцій з надання } \\
\text { медичних послуг; } \\
-\quad \text { Включення до } \\
\text { складу витрат } \\
\text { платника ППП витрат } \\
\text { на охорону здоров’я; } \\
\text { - Виключення з } \\
\text { розрахунку загального } \\
\text { місячного } \\
\text { оподаткування доходу } \\
\text { платника ПДФО } \\
\text { вартості товарів та } \\
\text { послуг на охорону } \\
\text { здоров’я; } \\
-\quad \text { Включення до } \\
\text { податкової знижки з } \\
\text { ПДФО вартості } \\
\text { товарів і послуг на } \\
\text { охорону здоров'я. }\end{array}$ \\
\hline \multicolumn{4}{|c|}{$\begin{array}{l}\text { 2. Ринок медичного обладнання, технологій та новацій } \\
\text { у галузі охорони здоров'я }\end{array}$} \\
\hline \multirow{3}{*}{$\begin{array}{c}\text { Адміністративні } \\
\text { (директивні) } \\
\text { методи }\end{array}$} & \multicolumn{3}{|c|}{ Економічні методи } \\
\hline & & \multicolumn{2}{|c|}{$\begin{array}{l}\text { Непрямі економічні методи, направлені } \\
\text { на стимулювання }\end{array}$} \\
\hline & $\begin{array}{c}\text { Прямі } \\
\text { економічні } \\
\text { методи }\end{array}$ & $\begin{array}{c}\text { Розширення } \\
\text { пропозиції та } \\
\text { підвищення } \\
\text { якості }\end{array}$ & $\begin{array}{c}\text { Розширення } \\
\text { платоспроможного } \\
\text { попиту на товари та } \\
\text { послуги на ринку }\end{array}$ \\
\hline $\begin{array}{l}\text { - Захист прав } \\
\text { інтелектуальної } \\
\text { власності шляхом } \\
\text { патентування } \\
\text { об’єктів } \\
\text { інтелектуальної } \\
\text { власності. }\end{array}$ & $\begin{array}{l}\text { - Фінансова } \\
\text { підтримка за } \\
\text { рахунок } \\
\text { державних } \\
\text { видатків на } \\
\text { наукові } \\
\text { медичні } \\
\text { дослідження. }\end{array}$ & - & $\begin{array}{l}\text { - Звільнення від } \\
\text { оподаткування } \\
\text { акцизним податком } \\
\text { операцій з реалізації } \\
\text { легкових автомобілів } \\
\text { для інвалідів; }\end{array}$ \\
\hline
\end{tabular}


Продовження таблиці 2

\begin{tabular}{|c|c|c|c|}
\hline 1 & 2 & 3 & 4 \\
\hline $\begin{array}{l}\text { - Захист прав } \\
\text { інтелектуальної } \\
\text { власності шляхом } \\
\text { патентування } \\
\text { об’єктів } \\
\text { інтелектуальної } \\
\text { власності. }\end{array}$ & $\begin{array}{l}\text { - Фінансова } \\
\text { підтримка за } \\
\text { рахунок } \\
\text { державних } \\
\text { видатків на } \\
\text { наукові } \\
\text { медичні } \\
\text { дослідження. }\end{array}$ & - & $\begin{array}{l}\text { - Застосування } \\
\text { зниженої ставки ПДВ } \\
\text { до операцій з } \\
\text { експорту/імпорту } \\
\text { виробів медичного } \\
\text { призначення; } \\
\text { - Застосування } \\
\text { зниженої ставки ПдВ } \\
\text { до операцій з } \\
\text { експорту/імпорту } \\
\text { медичних виробів } \\
\text { та/або медичного } \\
\text { обладнання для } \\
\text { клінічних } \\
\text { випробувань. }\end{array}$ \\
\hline \multicolumn{4}{|c|}{ 3. Фармацевтичний ринок } \\
\hline \multirow{3}{*}{$\begin{array}{c}\text { Адміністративні } \\
\text { (директивні) } \\
\text { методи }\end{array}$} & \multicolumn{3}{|c|}{ Економічні методи } \\
\hline & \multirow[b]{2}{*}{$\begin{array}{c}\text { Прямі } \\
\text { економічні } \\
\text { методи }\end{array}$} & \multicolumn{2}{|c|}{$\begin{array}{c}\text { Непрямі економічні методи, направлені } \\
\text { на стимулювання }\end{array}$} \\
\hline & & $\begin{array}{c}\text { Розширення } \\
\text { пропозиції та } \\
\text { підвищення } \\
\text { якості }\end{array}$ & $\begin{array}{c}\text { Розширення } \\
\text { пропозиції та } \\
\text { підвищення якості } \\
\text { товарів і послуг на } \\
\text { ринку } \\
\end{array}$ \\
\hline $\begin{array}{l}\text { - Реєстрація та } \\
\text { стандартизація } \\
\text { якості лікарських } \\
\text { засобів і виробів } \\
\text { медичного } \\
\text { призначення; } \\
\text { - Ліцензування } \\
\text { діяльності з } \\
\text { виробництва, } \\
\text { оптової, роздрібної } \\
\text { торгівля } \\
\text { лікарськими } \\
\text { засобами та } \\
\text { виробами } \\
\text { медичного } \\
\text { призначення; }\end{array}$ & $\begin{array}{l}\text { - Фінансова } \\
\text { підтримка за } \\
\text { рахунок } \\
\text { державних } \\
\text { видатків на } \\
\text { закупівлю } \\
\text { лікарських } \\
\text { засобів і } \\
\text { виробів } \\
\text { медичного } \\
\text { призначення. }\end{array}$ & $\begin{array}{l}\text { - Виключення з } \\
\text { переліку платників } \\
\text { збору за } \\
\text { впровадження } \\
\text { деяких видів } \\
\text { підприємницької } \\
\text { діяльності аптек, } \\
\text { провадження } \\
\text { діяльності щодо } \\
\text { постачання } \\
\text { лікарських засобів } \\
\text { з придбанням } \\
\text { пільгового } \\
\text { торгового пакету. }\end{array}$ & $\begin{array}{l}\text { - Застосування } \\
\text { зниженої ставки ПДВ } \\
\text { до операцій з } \\
\text { експорту/імпорту } \\
\text { лікарських засобів; } \\
\text { - Звільнення від } \\
\text { оподаткування митом } \\
\text { фармацевтичної } \\
\text { продукції; } \\
\text { - Застосування } \\
\text { зниженої ставки ПдВ } \\
\text { до операцій з } \\
\text { експорту/імпорту }\end{array}$ \\
\hline $\begin{array}{l}\text { - Державне } \\
\text { регулювання цін } \\
\text { на лікарські засоби } \\
\text { і вироби } \\
\text { медичного } \\
\text { призначення. }\end{array}$ & & & $\begin{array}{l}\text { лікарських засобів } \\
\text { для клінічних } \\
\text { випробувань. }\end{array}$ \\
\hline
\end{tabular}


Закінчення таблиці 2

\begin{tabular}{|c|c|c|c|}
\hline 1 & \begin{tabular}{l|l}
2 & \\
\end{tabular} & \begin{tabular}{|l|}
$\mathbf{3}$ \\
\end{tabular} & 4 \\
\hline \multicolumn{4}{|c|}{ 4. Ринок медичного страхування } \\
\hline \multirow[b]{3}{*}{$\begin{array}{c}\text { Адміністративні } \\
\text { (директивні) } \\
\text { методи }\end{array}$} & \multicolumn{3}{|c|}{$\begin{array}{l}\text { Економічні методи } \\
\end{array}$} \\
\hline & \multirow[b]{2}{*}{$\begin{array}{c}\text { Прямі } \\
\text { економічні } \\
\text { методи }\end{array}$} & \multicolumn{2}{|c|}{$\begin{array}{c}\text { Непрямі економічні методи, } \\
\text { направлені на стимулювання } \\
\end{array}$} \\
\hline & & $\begin{array}{c}\text { Розширення } \\
\text { пропозиції та } \\
\text { підвищення } \\
\text { якості }\end{array}$ & $\begin{array}{c}\text { Розширення } \\
\text { пропозиції та } \\
\text { підвищення якості } \\
\text { товарів і послуг на } \\
\text { ринку }\end{array}$ \\
\hline $\begin{array}{l}\text { - Ліцензування } \\
\text { діяльності зі } \\
\text { страхування. }\end{array}$ & $\begin{array}{l}\text { - Діяльність } \\
\text { Фонду } \\
\text { соціального } \\
\text { страхування від } \\
\text { нещасних } \\
\text { випадків на } \\
\text { виробництві та } \\
\text { профес. } \\
\text { захворювань. }\end{array}$ & - & $\begin{array}{l}\text { - Включення до } \\
\text { витрат платника } \\
\text { ППП внесків на } \\
\text { страхування } \\
\text { здоров'я, } \\
\text { обов'язковість якого } \\
\text { передбачена } \\
\text { законодавством. }\end{array}$ \\
\hline \multicolumn{4}{|c|}{$\begin{array}{l}\text { 5. Ринок праці медичного персоналу та ринок освітніх послуг } \\
\text { у сфері охорони здоров'я } \\
\end{array}$} \\
\hline \multirow[b]{3}{*}{$\begin{array}{c}\text { Адміністративні } \\
\text { (директивні) } \\
\text { методи }\end{array}$} & \multirow[b]{3}{*}{$\begin{array}{c}\text { Прямі } \\
\text { економічні } \\
\text { методи }\end{array}$} & \multicolumn{2}{|c|}{ Економічні методи } \\
\hline & & \multicolumn{2}{|c|}{$\begin{array}{c}\text { Непрямі економічні методи, } \\
\text { направлені на стимулювання } \\
\end{array}$} \\
\hline & & $\begin{array}{c}\text { Розширення } \\
\text { пропозиції та } \\
\text { підвищення } \\
\text { якості }\end{array}$ & $\begin{array}{c}\text { Розширення } \\
\text { пропозиції та } \\
\text { підвищення якості } \\
\text { товарів і послуг на } \\
\text { ринку } \\
\end{array}$ \\
\hline $\begin{array}{l}\text { - Ліцензування } \\
\text { діяльності та } \\
\text { акредитація } \\
\text { освітніх закладів; } \\
\text { - Стандартизація } \\
\text { якості освітніх } \\
\text { послуг. }\end{array}$ & $\begin{array}{l}\text { - Фінансова } \\
\text { підтримка за } \\
\text { рахунок } \\
\text { державних } \\
\text { видатків } \\
\text { підготовки, } \\
\text { перепідготовки і } \\
\text { підвищення } \\
\text { кваліфікації та } \\
\text { оплату праці } \\
\text { медичних кадрів. }\end{array}$ & - & - \\
\hline
\end{tabular}

Джерело: адаптовано ${ }^{28}$

4) за типом інструментів, що застосовуються на ринках охорони здоров'я:

${ }^{28}$ Іванов Ю.Б., Бережна Ю.В. Інструментарій державного регулювання сфери охорони здоров’я в Україні. Економіка і регіон. 2014. № 4. С. 101-106. 
- інструменти підвищення якості послуг (товарів) медичних послуг;

- інструменти підвищення ефективного попиту на медичні послуги та товари ${ }^{29}$.

Таким чином, аналіз даних таблиці 2 підтверджує, що основними інструментами, які застосовуються на всіх типах ринку охорони здоров'я, $€$ прямі адміністративні методи (а саме: ліцензування, акредитація, стандартизація та контроль ціноутворення), прямі економічні методи (це фінансова підтримка різних медичних заходів, наприклад, медичних наукових досліджень, освіти та навчання, придбання медичного обладнання, фармацевтичних препаратів тощо) та непрямі економічні методи (представлені політикою податкового регулювання).

Можна стверджувати, що частка прямих адміністративноекономічних методів у системі державного регулювання в Україні становить $40 \% ; 15 \%$ - непрямі економічні методи, що спрямовані на стимулювання ефективного попиту на медичні послуги та товари; 5\% непрямі економічні методи, що спрямовані на стимулювання якості постачання та надання медичних послуг (товарів) у системі методів державного регулювання (рис. 3).
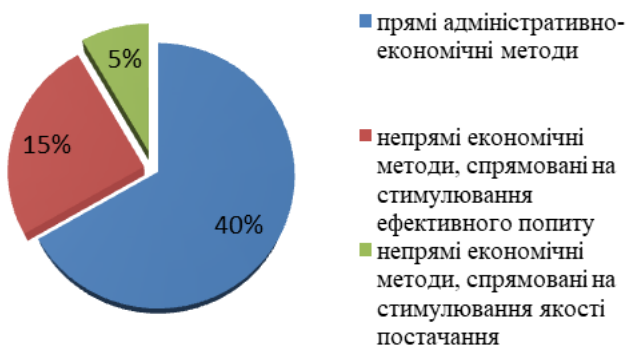

Рис. 3. Частка використання методів державного регулювання в Україні

Джерело: розроблено автором

Можна впевнено стверджувати, що найбільш ефективним механізмом державного регулювання у світі у будь-якій галузі економіки є податкове стимулювання та займає одне з провідних місць у системі непрямих економічних методів державного регулювання охорони здоров'я в Україні.

${ }^{29}$ Іванов Ю.Б., Бережна Ю.В. Інструментарій державного регулювання сфери охорони здоров’я в Україні. Економіка і регіон. 2014. № 4. С. 101-106. 
Результати аналізу інструментарію державного регулювання сфери охорони здоров'я в Україні свідчать про його фрагментарний характер, адже не забезпечують державне регулювання всіх взаємопов'язаних ринків сфери охорони здоров'я та якість системи управління закладами охорони здоров'я, що значно ускладнюе процес автономізації, формування ринкових відносин та знижує результативність процесу реформування національної системи охорони здоров'я.

Проведене дослідження механізму державного регулювання сфери охорони здоров'я дало можливість сформулювати необхідність реалізації наступних завдань державного регулювання охорони здоров'я, серед яких провідне місце посідають механізми забезпечення сприятливих умов для діяльності закладів охорони здоров'я, зокрема:

- правове регулювання організаційної, фінансової та господарської діяльності закладів охорони здоров'я;

- бюджетне та податкове регулювання, що дозволяє створити умови для оптимізації податкової бази закладів охорони здоров'я;

- прийняття загальнодержавних та регіональних цільових програм, що сприяють реалізації прав громадян на отримання якісної медичної допомоги в рамках системи медичного страхування;

- передача у власність місцевих громад об'єктів, які перебувають у державній власності, необхідних для надання медичних послуг;

- методична підтримка, діяльності закладів охорони здоров'я;

- підготовка та підвищення кваліфікації кадрів закладів охорони здоров'я;

- інформаційна підтримка, у т.ч. роз'яснення населенню їхніх конституційних прав на отримання безкоштовної медичної допомоги, про роль населення у створенні системи громадського контролю за діяльністю закладів охорони здоров'я.

\section{3. Організаційно-функціональна структура}

\section{національної системи охорони здоров'я України}

Аналіз організаційної структури національної системи охорони здоров'я підтверджує, що в Україні система охорони здоров'я створена за принципом вертикального підпорядкування. Схематично організаційно-функціональна структура системи охорони здоров'я представлена на рис. 4. 


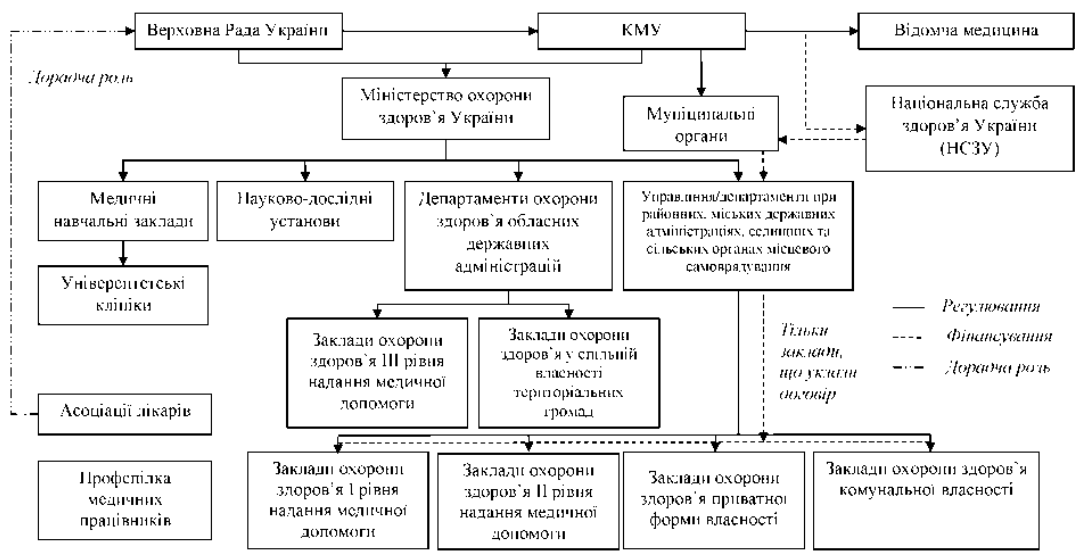

Рис. 4. Організаційно-функціональна структура системи охорони здоров'я України

Джерело: розроблено автором

Вищим законодавчим органом у сфері охорони здоров'я $є$ Верховна Рада України, яка формує нормативно-законодавчу базу функціонування та фінансування сфери охорони здоров'я України.

Уряд України $\epsilon$ вищою виконавчою ланкою, яка делегувала повноваження щодо стратегічного планування, вироблення політики та стратегії розвитку і реформування, а також поточного управління, визначення обсягів фінансування, закупівлі ліків та розподілу їх за деякими програмами Міністерству охорони здоров'я. Міністр охорони здоров'я призначається Верховною Радою України за поданням Голови Уряду (прем'єр-міністра), відповідає перед Урядом та Верховною Радою, звільняється з посади Верховою Радою.

Міністерству охорони здоров'я підпорядковані вищі та середні навчальні заклади, науково-дослідні установи у сфері охорони здоров'я, а також департаменти охорони здоров'я обласних державних адміністрацій.

Департаментам при обласних державних адміністраціях підпорядковані управління / департаменти при районних, міських державних адміністраціях та селищних та сільських органах місцевого самоврядування, заклади охорони здоров'я третинного рівня, заклади охорони здоров'я у спільній власності територіальних громад, а також приватної форми власності. 
Департаменти при обласних державних адміністраціях здійснюють планування діяльності та поточне керівництво усіма підпорядкованими об'єктами.

Управлінням та департаментам при районних, міських державних адміністраціях та селищних та сільських органах місцевого самоврядування підпорядковані заклади охорони здоров'я первинного та / чи вторинного рівня, заклади охорони здоров'я, підпорядковані на правах комунальної власності, а також заклади приватної форми власності.

За даними Державної служби статистики та офіційного веб-порталу Верховної Ради України, загальна кількість управлінь та департаментів за адміністративно-територіальною ознакою станом на 2019 рік:

- Департаменти при обласних державних адміністраціях - 27 од.;

- Департаменти при районних державних адміністраціях - 490 од.;

- Управління та департаменти при міських державних адміністраціях - 461 од.;

- Управління та департаменти селищних та органах місцевого самоврядування - 883 од.;

- Управління та департаменти при сільських органах місцевого самоврядування - 28376 од.

Міністерство охорони здоров'я, обласні та районні департаменти та управління охорони здоров'я здійснюють моніторинг діяльності закладів охорони здоров'я, свого підпорядкування, а також $\epsilon$ відповідальні за якість надання медичної допомоги. Реалізація контролю якості здійснюється переважно за допомогою адміністративних методів державного регулювання, а саме протоколів лікування, механізмів ліцензування та акредитації діяльності закладів охорони здоров'я, сертифікації медичного персоналу (лікарів). Вимоги щодо якості надання медичних послуг $є$ рівними як для приватних, так i державних закладів ${ }^{30}$.

У складі Міністерства охорони здоров'я України діють консультативні та дорадчі органи, кваліфікаційні, наукові, а також науково-кваліфікаційні комісії.

Міністерству безпосередньо підпорядковані науково-дослідні установи з питань охорони здоров'я та високоспеціалізованої медичної допомоги.

Особливістю національної системи охорони здоров'я є безпосереднє підпорядкування вищих медичних навчальних закладів освіти як

${ }^{30}$ Рудий С.А., Гук А.П. Порівняння структурних елементів управління систем охорони здоров'я окремих країн Свропи та України. Економіка $і$ право охорони здоров 'я. 2016. № 2(4). С. 89-99. 
Міністерству освіти та науки України, так і Міністерству охорони здоров'я. Заклади вищої освіти можуть мати власні університетські клініки - третинна ланка надання медичної допомоги (наприклад, у підпорядкуванні Одеському національному медичному університету знаходяться Університетська клініка та Багатопрофільний медичний центр), де здійснюється підготовка медичних фахівців, наукова діяльність і надання висококваліфікованої медичної допомоги ${ }^{31}$.

Іншою особливістю $€$ наявність відомчої медицини, що також фінансується за кошти державного бюджету та обслуговує вузьку професійну групу (в Україні це медичне відділення Державного управління справами). Проте реформа охорони здоров'я передбачає ліквідацію відомчої медицини з метою формування єдиного медичного простору та рівних можливостей для всіх груп населення. Ліквідація відомчої медицини передбачається на етапі трансформації механізму фінансування вторинної та третинної ланки медичної допомоги ${ }^{32}$.

Також у межах національної системи охорони здоров'я України існують профспілкові організації працівників галузі, а також різноманітні лікарські асоціації та товариства, які $\epsilon$ членами Національної лікарської ради України (близько 43 од.). Вони $\epsilon$ представниками певних фахових груп працівників медичної галузі. $€$ неприбутковими добровільними громадськими об'єднаннями, що відіграють важливе значення в регулюванні охорони здоров'я України, встановленні медичних стандартів, сприянні професійного розвитку медичних кадрів, а також захисті прав медичних працівників. Лікарські асоціації та товариства $\epsilon$ механізмом «професійного регулювання медичної діяльності» в Україні ${ }^{33}$ за рахунок членства авторитетних вчених медичної галузі (одним із завдань $\epsilon$ сприяння розвитку вітчизняної медичної науки).

Лікарські асоціації безпосередньо подають до Комітету Верховної Ради 3 питань охорони здоров'я рекомендації та проекти Законів, офіційно висловлюють думку медичної громадськості у зверненнях до

${ }^{31}$ Корнійчук О.П. Трансформація системи охорони здоров'я України: стан та перспективи. Украӥнський медичний часопис. 2013. № 4(96). URL : https://www.umj.com.ua/article/63259/transformaciya-sistemi-oxoroni-zdorov-yaukraini-stan-ta-perspektivi.

32 Устинов А.В. Медична реформа: відомчі медичні заклади стануть доступними для усіх громадян. Украӥнський медичний часопис опline. Актуальні питання медичної практики : веб-сайт. 2019.2 URL https://www.umj.com.ua/article/140879/medichna-reforma-vidomchi-medichni-zakladistanut-dostupnimi-dlya-usih-gromadyan.

33 Асочіачія прачівників лікарняних кас Украйни : офіційний веб-сайт. URL : http://likkasa.com/. 
Міністерства охорони здоров'я та уряду щодо питань та існуючих проблем у сфері охорони здоров'я.

Елементами національної системи охорони здоров'я відповідно до функціоналу $є$ такі державні організації, які здійснюють соціальне страхування: Пенсійний фонд України, Державна служба зайнятості (виконавча дирекція Фонду загальнообов'язкового державного соціального страхування України на випадок безробіття), Фонд соціального страхування 3 тимчасової втрати працездатності (фінансування санаторно-курортного лікування та оздоровлення застрахованих осіб і членів їхніх сімей), Фонд соціального захисту інвалідів (фінансує витрати на медичну i соціальну допомогу потерпілим на виробництві $)^{34}$. Ці організації є страховими, тому можуть бути підгрунтям для запровадження моделі соціального медичного страхування.

У межах організаційно-функціональної системи також здійснює свою діяльність Національна служба здоров'я України (НСЗУ), яка виконує функції єдиного національного закупівельника медичних послуг. Це новостворена структура (перший етап реформування галузі).

Ми погоджуємося 3 думкою українських науковців I.М. Солоненка та С.Я. Пака, що «структура управління охороною здоров'я на регіональному та місцевому рівнях $€$ надто недосконалою, а управління системою охорони здоров'я в Україні не відповідає до сучасним соціально-економічним умовам» ${ }^{35}$.

Окреслені проблеми призводять до відсутності орієнтації системи надання медичної допомоги на пацієнта, яка б враховувала та відповідала б його особистим вимогам, потребам та цінностям, а також справедливого підходу до надання якісної медичної допомоги незалежно від соціально-економічного статусу пацієнта та його особових характеристик.

У таких умовах стає очевидним, що національна система охорони здоров'я України потребує послідовних і глибоких інституціональних та структурних перетворень. Ми погоджуємося 3 думкою I.M. Солоненко, що «акцент пріоритетів у реформі охорони здоров'я потрібно активно перемістити на оптимізацію управління на усіх рівнях» ${ }^{36}$. Найбільш актуальним напрямом цих перетворень $є$ розвиток

${ }^{34}$ Гладун 3.С. Державне управління в галузі охорони здоров’я. Тернопіль : Академкнига, 2000. $312 \mathrm{c.}$

35 Солоненко I.M., Пак С.Я. Удосконалення організаційно-правових засад діяльності місцевих органів влади у сфері охорони здоров'я в України. Сучасні питання економіки і права. 2011. Вип. 1. С. 102-110.

36 Солоненко I.M., Пак С.Я. Удосконалення організаційно-правових засад діяльності місцевих органів влади у сфері охорони здоров'я в України. Сучасні питання економіки і права. 2011. Вип. 1. С. 114. 
медичного менеджменту за рахунок якісних механізмів удосконалення засад фінансового, кадрового та стратегічного менеджменту закладів охорони здоров'я. Усе це покликано створити соціально-орієнтовану, розвинену систему управління, яка здатна забезпечити якість, своєчасність та доступність медичної допомоги для населення.

\section{ВИСНОВКИ}

Здійснений аналіз дав автору змогу визначити сутність парадигми державного регулювання у сфері охорони здоров'я, що являє собою сукупність отриманих і вироблених знань, управлінських рішень та підходів до вирішення проблем функціонування й модернізації сфери охорони здоров'я, які адекватно відображають реальний стан системи охорони здоров'я в межах визначення шляхів іiі розвитку в умовах трансформації ринкового механізму господарювання, за допомогою державного регулювання ринку охорони здоров'я, організації процесу надання медичної допомоги населенню та раціонального й ефективного використання наявних ресурсів галузі. Таким чином, сучасна парадигма управління у сфері охорони здоров'я спрямована на модифікацію галузі під впливом розвитку ринкових відносин та об'єктивної необхідності раціонального використання обмежених ресурсів. Вона має відповідати національній економічній парадигмі, що склалася у країні.

Здійснене дослідження підтверджує, що основною метою розвитку сучасної парадигми державного регулювання й управління у сфері охорони здоров'я є впровадження управлінських технологій у галузі, що засновані на міжгалузевому підході та передбачають створення сприятливих умов для макроекономічного розвитку закладів охорони здоров'я. Перехід до нової парадигми зумовлений насамперед становленням нових соціально-економічних відносин між постачальниками та споживачами медичної послуги. Це зумовлює необхідність подальшого поглибленого аналізу парадигми управління, a саме засад фінансового i стратегічного менеджменту, а також управління персоналом цієї галузі.

Використання такої парадигми як концептуальної моделі, що відображає сучасний стан системи охорони здоров'я i шляхи іiі розвитку в умовах ринкової економіки, сприяє науково обгрунтованому стратегічному управлінню організацією надання медичної допомоги населенню, державному регулюванню ринку охорони здоров'я та раціональному використанню ресурсів галузі.

\section{АНОТАЦІЯ}

Досліджена проблема державного регулювання системи управління у сфері охорони здоров'я, зокрема, нормативно-правові документи, що іiі регулюють на національному i світовому рівнях. Сформовані 
концептуальні засади державного регулювання сфери охорони здоров'я. Ідентифіковані та класифіковані методи державного регулювання у сфері охорони здоров'я, що найчастіше застосовуються в національній практиці управління. Проаналізовано організаційно-функціональну структуру національної системи охорони здоров’я України.

\section{ЛІТЕРАТУРА}

1. Конституція України : в редакції від 01 січня 2020 р. № 254к/96-ВР. Відомості Верховної Ради Украӥни. 1996. № 30. URL : https://zakon.rada.gov.ua/laws/show/254\%D0\%BA/96-\%D0\%B2\%D1\%80 (дата звернення: 22.01.2020).

2. Державна служба статистики України : офіційний веб-сайт. URL : http://www.ukrstat.gov.ua/ (дата звернення: 27.10.2019).

3. Національна лікарська рада України : офіційний веб-сайт. URL : http://www.vult.org.ua/?page_id=232 (дата звернення: 19.02.2020).

4. Основи законодавства України про охорону здоров'я : Закон України від 19 листопада 1992 р. (№ 2801-XII, редакція від 16 січня 2020 p.) URL : https://zakon.help/law/2801-XII (дата звернення: 15.02.2020).

5. Гладун 3.С. Адміністративно-правове регулювання охорони здоров'я населення в Україні : монографія. Київ : Юрінком Інтер, 2007. $720 \mathrm{c}$.

6. Гладун 3.С. Державне управління в галузі охорони здоров'я. Тернопіль : Академкнига, 2000. 312 с.

7. Державне регулювання економіки (2006). URL : https://library.if.ua/book/72/5235.html (дата звернення: 15.02.2020).

8. Іванов Ю.Б., Бережна Ю.В. Інструментарій державного регулювання сфери охорони здоров'я в Україні. Економіка $і$ регіон. 2014. № 4. C. 101-106.

9. Лікарські асоціації - реальна влада в медицині? Ваше здоров'я : веб-сайт. 2012. URL : https://www.vz.kiev.ua/likarski-asociaciyi-realnavlada-v-medicini/ (дата звернення 18.02.2020).

10. Петрова С.В. Державна політика України у сфері охорони здоров'я в контексті реформи медичного обслуговування. Теорія та практика державного управління $i$ місиевого самоврядування: Електронний збірник. 2014. № 2. URL : http://el-zbirndu.at.ua/index/zmist_2014_2/0-16 (дата звернення: 05.02.2019).

11. Ридзель Ю.М. Державне регулювання інноваційного розвитку сфери охорони здоров'я України : дис. ... канд. екон. наук. Чернігів, $2020.258 \mathrm{c}$.

12. Солоненко I.M., Пак С.Я. Удосконалення організаційноправових засад діяльності місцевих органів влади у сфері охорони 
здоров'я в України. Сучасні питання економіки і права. 2011. Вип. 1. C. $102-110$.

13. Устинов А.В. Медична реформа: відомчі медичні заклади стануть доступними для усіх громадян. Украӥнський медичний часопис online. Актуальні питання медичної практики : веб-сайт. 2019. URL : https://www.umj.com.ua/article/140879/medichna-reforma-vidomchimedichni-zakladi-stanut-dostupnimi-dlya-usih-gromadyan (дата звернення: 18.02.2020).

14. Шевчук В.В. Підходи до реалізації механізмів державного регулювання інноваційного розвитку системи охорони здоров'я України. Наукові праиі [Чорноморського державного університету імені Петра Могили комплексу «Києво-Могилянська академія»]. Сер. : Державне управління. 2014. Т. 235. Вип. 223. С. 128-132.

15. Шевчук В.В. Удосконалення державного регулювання інноваційного розвиту системи охорони здоров'я України : дис. ... канд. наук з держ. упр. Миколаїв, 2017. 219 с.

16. Швайка Л.А. Державне регулювання економіки : навчальний посібник. Київ : Знання, 2006. 435 с.

17. Юридична енциклопедія : в 6 т. Т. 3. Київ : Вид-во «Укр. енцикл.» ім. М.П. Бажана, 2001. 782 с.

18. Charter adopted at an international conference on health promotion. The move towards a new public health (November 17-21, 1986 Ottawa, Ontario, Canada). URL : https://www.who.int/healthpromotion/ conferences/previous/ottawa/en/ (дата звернення: 17.09.2019).

19. Charter on Social Rights №. 995 418 (February 15, 1982). URL : http://zakon.rada.gov.ua/laws/show/995_418?lang=en (дата звернення: 17.09.2019).

20. European Code of Social Security. Treaty № 048. URL : https://www.coe.int/en/web/conventions/full-list/-/conventions/treaty/048 (дата звернення: 17.09.2019).

21. Truba V., Borshch V., Haran O. Methodological frameworks for state regulation of health care system in the post-soviet countries. Baltic Journal of economic studies. 2018. Vol. 4. N 5. Pp. 364-370. DOI: https://doi.org/10.30525/2256-0742/2018-4-5-364-370.

\section{Information about the author:} Borshch V. I., Doctor of Economic Sciences, Associate Professor, Vice-rector for Prospective Development

Odessa National Medical University 2, Valikhovskyi lane, Odessa, 65000, Ukraine 